\title{
An Exploration of Organizational Trust in Intercollegiate Athletic Departments
}

\author{
Jacob K. Tingle, Ed.D. \\ Trinity University
}

\begin{abstract}
Scholars in in educational leadership, business management, and organizational psychology have thoroughly explored the construct of organizational trust. While trust has attracted some attention from sport management scholars, the research has primarily focused on the individual, rather than organization. This manuscript provides an overview of the organizational trust literature with specific application to the area of intercollegiate athletic departments. Additionally, the Athletic Department Trust Scale (ADTS) is introduced as an instrument to measure organizational trust in the setting. The procedures taken to refine and test the instrument are summarized. Results revealed the ADTS as psychometrically sound. The instrument was used to explore three research questions related to coaching tenure and status. Analysis of Variance (ANOVA) revealed significant differences between coaching tenure and organizational trust. Practical and research implications are also presented.
\end{abstract}

Keywords: trust, intercollegiate athletics, coach, athletic directors, organization

Sports are uniquely situated in the American academy in contrast with other higher educational systems around the world. Indeed, the idea that sports enhance the collegiate experience or add to lessons learned inside the classroom permeates popular culture. Since the first intercollegiate rowing contest in 1852, however, the college sports experiment (Gerdy, 2006) has not always been associated with positive outcomes (Thelin, 1996).

Mitten, Musselman, and Burton (2009) reasoned that the motivation for having a successful athletic program is a rational acknowledgement of marketplace realities (i.e., universities are being forced to compete for ever scarcer resources). Unfortunately, this desire to be better than has led some to commit unethical or even illegal acts. As university administrators feel pressure to hire the best faculty, complete capital campaigns, and matriculate more students (e.g., to raise the university profile), they often lean on athletic directors to bring home the proverbial bacon. Consequently, some athletic directors and high profile coaches may understand this pressure as tacit approval to win-at-all-costs (Malloy \& Zakus, 1995). Indeed, when compelled by requirements to be successful and self-supporting, athletic department leaders often push the envelope in ways that threaten academic values (Clotfelter, 2011). In athletic departments, this mindset often manifests in the form of illegal recruiting, the use of ineligible athletes, and acceptance of academic fraud. Such corruption can erode a college athletic program's reputation, and for departmental personnel, can be detrimental to workplace outcomes, such as organizational commitment and job performance (Kihl \& Richardson, 2009).

Highlighting the problems associated with distrustful behavior and academic fraud, Kihl and Richardson (2009) reported there were long-lasting ramifications for an entire department, including coaches, players, and administrators. Specifically, they found that other university departments had higher levels of distrust for all athletics personnel - even those not directly involved with the scandal. They reported, "In the first 12 months post-corruption, the distrust felt among affected units generate[d] much hostility, which in turn impact[ed] relationships and productivity" (p. 292). Moreover, athletic personnel described being more cautious when interacting with faculty or staff from outside the department. Furthermore, with several high 
profile breaches in public trust (e.g., Baylor University, University of North Carolina) scholars and practitioners recognize a need for athletic departments to focus on building and maintaining trust (Lorenz, 1988).

The review of the literature indicates that most of the research on organizational trust has been conducted in the business environment and in the field of educational leadership, yet issues surrounding trust are important for intercollegiate athletic departments. With greater scrutiny over expenditures and organizational outcomes, the need to understand how trust manifests in intercollegiate athletic departments is paramount. While there has been significant examination of organizational behavior in intercollegiate sports, scant research has focused on trust in college athletic departments (Chelladurai \& Ogasawara, 2003; Dirks, 2000; Turner, 2001; Turner \& Chelladurai, 2005).

\section{Defining Trust}

Although trust is a difficult concept for both practitioners and researchers to grasp theoretically, it is important to study because high levels of trust result in elevated organizational performance (Dirks, 2000). Despite the outpouring of research over the past 20 years, the concept of trust is still rife with confusion and uncertainty (Nooteboom, 2007). Scholars have indicated that the difficulty in studying trust rests with the numerous definitions and seemingly endless number of research instruments used to explore the variable (Gambetta, 1988; Whitener, Brodt, Korsgaard, \& Werner, 1998). Hosmer (1995) stated, "There appears to be widespread agreement on the importance of trust in human conduct, but unfortunately there also appears to be equally widespread lack of agreement on a suitable definition of the construct" (p. 380). Moreover, Pfeffer (1993) contended that widespread divergence of this nature is an obstruction to scientific advancement. With those critiques in mind, rather than examining it as if it were a new construct, this research builds upon the scholarly work on trust developed in educational leadership.

Building on the work of Hoy and colleagues who have studied organizational trust for more than four decades, this study conceptualizes trust as having five facets: benevolence, competence, honesty, openness, and reliability (Hoy, Gage, \& Tarter, 2006; Smith \& Shoho, 2007; Tschannen-Moran, 2004). Additionally, in keeping with the seminal explorations of organizational trust (Baier, 1986; Pope, 2004; Rousseau, Sitkin, Burt, \& Camerer, 1998), this study includes risk or the dimension of vulnerability, in its definition. Because trust relies on interdependence, an important underlying element involves risk. Gambetta (1988) affirmed that trust is meaningless if there is no consequence, "For trust to be relevant there must be the possibility of exit, betrayal, and defection" (p. 217). Stated another way, if actions could be undertaken without risk and in conditions with absolute guarantees, trust would not be required (Hoy \& Tschannen-Moran, 1999; Rousseau et al., 1998).

After a thorough review of the organizational trust literature, this study defines trust as, "one party's willingness to be vulnerable to another party because of the confidence that the latter party is (a) benevolent, (b) reliable, (c) competent, (d) honest, and (e) open" (Hoy \& Tschannen-Moran, 1999, p. 189). The definition both captures the salient elements of trust found in contemporary organizational studies and has been applied in various educational settings. Hence, this definition of trust is the most relevant to guide the refinement of a research instrument to be used in an intercollegiate athletic department. What follows is an analysis of the trust facets found in the definition. 


\section{Benevolence}

Benevolence is commonly associated with trusting relationships and it occurs when the trusting party depends on the goodwill of another (Baier, 1986; Bromiley \& Cummings, 1995; Butler \& Cantrell, 1984; Cunningham \& MacGregor, 2000; Gabarro, 1978; Gambetta, 1988; McAllister, 1995). Benevolence exists when a special level of thoughtfulness and an authentic concern for the welfare of the trustor is present (Dietz \& Den Hartog, 2006; Mishra, 1996). It consists of three actions: 1) demonstrating sensitivity to the needs of others (Mishra, 1996);2) protecting the interests of others (Mayer, Davis, \& Schoorman, 1995); and 3) refraining from the exploitation of others (Bromiley \& Cummings, 1995).

\section{Competence}

The literature indicates that benevolence alone is not enough for one to be trusted (Smith \& Shoho, 2007). To be successful, the tasks required of coaches, athletes, or athletic directors involve high levels of competence or skill. According to Mishra (1996), competence refers to the trustee's ability to fulfill specific obligations using skills and knowledge. As such, a person who desires to be trusted must possess the requisite skills to complete the task at hand in a manner consistent with organizational values and procedures (Hoy, 2002; Goddard, Tschannen-Moran, \& Hoy, 2001). Furthermore, without the belief that colleagues possess the requisite competence, organizational trust is unlikely to develop (Mayer et al., 1995; Mishra, 1996).

\section{Honesty}

For many, honesty is the first image evoked when hearing the word trust. Indeed, the two are often equated. Assuredly a key component of trust, honesty is adherence to a set of principles, which include fairness and non-hypocritical behaviors. It consists of authenticity, character, and integrity (Hoy \& Tschannen-Moran, 2003). Many scholars found that one develops a reputation for being honest by telling the truth and keeping promises (Shoho \& Smith, 2004; Smith \& Shoho, 2007; Tschannen-Moran, 2004), while others reported that honesty exists when employees observe consistency between a supervisor's language and performance (Goddard et al., 2001).

\section{Openness}

Many scholars indicated that the willingness to listen and share information is important to the development of trusting relationships (Butler \& Cantrell, 1984; Gabarro, 1978; McEvily, Perrone, \& Zaheer, 2003; Mishra, 1996). Whitener et al. (1998) discovered that employees who participate in decision-making are more likely to develop trust in the organization. In fact, Gabarro (1978) found unfettered exchange and information sharing were important components of the openness. Accordingly, Goddard et al., (2001) defined openness as, "the extent to which relevant information is shared and not withheld" (p. 7).

Dirks and Ferrin (2001) reported that because trust promotes the free exchange of knowledge, parties become more willing to grant access to each other's information. That is, the more trusting a relationship, the more willing partners are to share information and the more willing partners are to share information, the more trusting the relationship becomes. According to Kouzes and Posner (2012) this disposition to share information indicates trust is selfperpetuating, i.e., trust begets trust. If one party is truly open, she exposes herself to great risk by divulging private, personal, or organizational information. By being open, the trustor is expressing confidence that the shared information will not be betrayed. As described by Hoy (2002), "Openness breeds trust, just as trust creates openness" (p. 92). 


\section{Reliability}

Reliability is the final facet of trust most often defined in the literature. Reliability relates to consistency and regularity of behavior and is the most frequently cited facet used by scholars to define trust (Butler \& Cantrell, 1984; Cunningham \& MacGregor, 2000; Dietz \& Den Hartog, 2006; Hoy \& Tschannen-Moran, 1999; Mishra, 1996; Shoho \& Smith, 2004; Smith \& Shoho, 2007). When managers engage in consistent behavior, it better allows employees to predict future behavior, which in turns leads to more confidence in the supervisor (Whitener et al., 1998). Reliability, however, is different from predictability. After all, one could predictably act selfishly or maliciously. That act of consistently damaging the welfare of another may indeed meet expectations (be predictable), but it would erode the foundation of trust. Reliability, therefore, goes beyond simply being consistent or predictable. It involves a firm belief that one's requirements will be addressed positively (Hoy \& Tschannen-Moran, 2003). As described by Goddard et al. (2001), reliability is not a one-time occurrence. Brenkert (1997) indicated managers earn the reliable label when they build a reputation for commitment, which may serve to identify them as a prospective trustworthy actor.

As described by Pope (2004) and Rousseau et al., (1998), if the trustor fails to make herself vulnerable or expose herself to some risk, the need for trust becomes less important. Given the relationship between a coach and an athletic director, it can be argued that vulnerability is part of the job description. As such, the five facets described above, though discrete, join with the concept of vulnerability to create an overall construct of organizational trust. Take for example an athletic director who exhibits concern for the well-being of subordinates (benevolence), performs her job at a high level (competence), is a forthright communicator (honesty), is open about her decision-making strategies (openness), but her actions are erratic (failing in reliability). The negatively perceived value will act as the meter by which the other four positive facets are ultimately gauged. Moreover, one would not trust someone known to have plans to cause us injury; one would not trust someone who was deceitful; and regardless of the trustee's level of benevolence, openness, and honesty, it would be hard to trust someone who does not possess essential job skills or knowledge. Thus, organizational trust is the sum of the perception of all five facets taken from the combined organizational constituents (Pope, 2004) joined with an element of risk or vulnerability on the part of the trustor.

\section{Trust in Organizations}

Many consider coaches to be the life blood of athletic departments. They are responsible for recruiting and coaching, held accountable for academic performance and graduation rates, and are blamed or lauded for departmental success (no matter how one defines success). Furthermore, in athletic departments, the internal constituents to coaches can broadly be defined as leader (athletic director), colleagues (other coaches), and student-athletes. Previous research has indicated that well-functioning organizations are infused with trust at all levels of the organization: up, laterally, and down the organizational chart. As such, an examination of trust in athletic departments should examine coaching staff's perception of trust among these three referent groups.

\section{Trust in Supervisor (Leader)}

Butler and Cantrell (1984) explored differences that existed between the conditions of trust when measured up the organizational chart. They discovered that certain facets of trust were 
more important when discussing bosses rather than subordinates. Indeed, individuals are more likely to consider organizational values as legitimate when they feel a high level of trust for those in positions of authority (Tyler \& Kramer, 1990). Tan and Tan (2000) found that "satisfaction with supervisor" and "increased innovation" were positively and significantly correlated with "trust in supervisor." McEvily et al. (2003) established that employees were more disposed to disclose weaknesses in skills and competencies, e.g., to be more open and honest, when they had higher levels of trust in their manager. Trust in leadership is important because it simultaneously supports maximizing the effort of organizational members and guiding those efforts toward a common end (Dirks \& Skarlicki, 2004). Furthermore, Schaubroeck, Lam, and Peng (2011) found that trust mediated the effect of leadership behavior on team performance.

Numerous studies have indicated that organizational members who trust their superiors are more likely to act in ways that benefit the entire organization (Dirks, 1999; McAllister, 1995; Snyder, 1990).

\section{Trust in Colleague (Other Coaches)}

While trust in the leader is paramount, it is important to study trust in all areas of the organization (Tschannen-Moran, 2004). Dirks and Skarlicki (2004) indicated, "Exploring trust from the viewpoint of peers is highly relevant in light of the growing presence of lateral relationships in organizations" (p. 32). Numerous studies have established that trust is critical to the development of positive relationships among work colleagues (Bromiley \& Cummings, 1995; Dirks \& Ferrin, 2002). Huang and Dastmalchian (2006) reported a significant relationship between collegial trust and job satisfaction. Barney and Hansen (1994) established that strong trustworthy behaviors between co-workers could be a source of competitive advantage. To that end, Pope (2004) found positive workplace outcomes such as decreased costs, increased innovation and collaboration, and improved communication were associated with trusting relationships in the workplace.

\section{Rationale for the Study}

While there is a dearth of literature on trust in athletic departments, there has been some exploration of trust in the realm of athletic competition. In their study of 24 Canadian Interuniversity Sport programs, Kerwin and Doherty (2012) found trust to have a significant moderating effect between task conflict and further relationship conflict. Gould, Guinan, Greenleaf, and Chung (2002) found that a coach's inability to establish trust with his/her athletes and to manage crises while making evenhanded decisions influenced his/her perceived effectiveness. Yukelson (1997) indicated that the inability of an athletic director to create a trusting environment can lead to feelings of disconnectedness and decreased motivation for coaches. Moreover, evidence exists that indicates a negative relationship between job satisfaction and turnover (Mathieu \& Zajac, 1990). The effects of turnover, including cost (Turner, 2001) and impact on team performance (McQueary, 1997) indicate a strong reason to retain coaches by focusing on the creation of an open, collegial, and trusting environment (Chelladurai \& Ogasawara, 2003). Furthermore, Turner and Chelladurai (2005) found it much more cost effective to retain a competent coach than to replace and train a new one. Additionally, researchers have shown that trust develops over a period of time (Baier, 1986; Jones \& George, 1998). Thus, reducing turnover in organizations is important, both as a means to reduce expenses and to facilitate the development of a trusting environment. 
Trust, however, is difficult to establish in large, complex organizations. Like others, McEvily et al. (2003) found that because it is complex and multi-layered, trust takes time to develop. It develops through a series of interactions, in which co-workers update information about each other and gain confidence in each other's reliability, competence, and honesty. Put simply, the behavior of the leader matters in regards to creating an environment conducive to retaining employees in non-academic university positions (Smerek \& Peterson, 2006), in National Collegiate Athletic Association (NCAA) Division I (D-I) athletic departments (Snyder, 1990), and in NCAA Division III (D-III) athletic departments (Weaver \& Chelladurai, 2002; Yusof, 1998).

The limited existing research notwithstanding, trust appears to be an important organizational process in athletic departments. Furthermore, while intercollegiate athletic departments exist in the broader educational landscape, they are distinctive from an operational standpoint. As such, it is necessary to have a valid and reliable instrument that can be used in this unique context. The purpose of this study therefore was to: a) develop a psychometrically sound instrument to measure organizational trust in intercollegiate athletic departments; and b) to test the utility of the athletic department trust instrument by examining the degree of trust among coaches at different employment levels (head or assistant) and exploring the relationship of coaching tenure and trust. As such, three general research questions guided the exploration:

1) Are there statistically significant differences between overall tenure in the coaching profession in the degree of organizational trust?

2) Are there statistically significant differences between tenure for coaches at an institution in the degree of organizational trust?

3) Are there statistically significant differences between coaching classification (head or assistant) in the degree of organizational trust?

What follows is a description of the refinement and testing of an instrument to study trust in all directions on the organizational chart: down, laterally, and up.

\section{Instrument Refinement Process}

Existing literature provides a foundation for the importance of developing a scale that measures organizational trust in intercollegiate athletic departments. No athletic-specific instruments that either focus on the three referent groups (athletic director, coaches, and studentathletes) or the five trust facets as operationalized for this research exist. As such, this study developed the Athletic Department Trust Scale (ADTS) in multiple stages by refining an instrument used in another higher education setting. Specifically, the ATDS' design was based on Shoho and Smith's (2004) and Smith and Shoho's (2007) Higher Education Faculty Trust Inventory (HEFTI). In both studies, HEFTI measured higher education faculty perceptions of trust in colleagues, trust in supervisors, and trust in students along the five facets of trust as operationalized in this study. As a valid and reliability instrument, the HEFTI provided a strong foundation, but since there are important operational differences between academic and athletic departments, the instrument needed modification.

The HEFTI authors granted approval to modify its conceptual design. Initially the HEFTI was a 30-item inventory, but was later modified to 28-items (Shoho \& Smith, 2004; Smith \& Shoho, 2007). This study began with the original 30-item HEFTI as a base, as use of a larger inventory would aid in construct analysis and factor development. It was important to ensure that all five trust facets (benevolence, competence, honesty, openness, and reliability) were 
represented in each trust referent group (athletic director, coaches, and student-athletes). As such, the ADTS consisted of at least eight items designed to measure each of the three referent groups, in which at least one item measured each facet of trust. Sample items are presented in Table 1. Because changes were made to the response items and the important differences in educational contexts, the ADTS needed to be pilot tested.

Table 1 Sample Items for Each Facet of Athletic Department Trust

\begin{tabular}{lll}
\hline Trust Dimension & Sample Item \\
\hline $\begin{array}{l}\text { Coaching Staff's } \\
\text { Trust in Coaching } \\
\text { Staff }\end{array}$ & $\begin{array}{l}\text { The coaching staff in our department is suspicious of each } \\
\text { other* (benevolence) } \\
\text { The coaching staff in our department is open with each other } \\
\text { (openness) }\end{array}$ \\
$\begin{array}{ll}\text { Coaching Staff's } \\
\text { Trust in Athletic } \\
\text { Director }\end{array}$ & - & $\begin{array}{l}\text { The A.D. in our department is competent in performing his or } \\
\text { her job (competence) } \\
\text { The coaching staff in our department can rely on the A.D } \\
\text { (reliability) }\end{array}$ \\
$\begin{array}{l}\text { Coaching Staff's } \\
\text { Trust in Student- } \\
\text { Athlete }\end{array}$ & $\begin{array}{l}\text { Student-athletes in our department are secretive (openness) } \\
\text { The coaching staff in our department believes what student- } \\
\text { athletes say (honesty) }\end{array}$ \\
\hline
\end{tabular}

*This item is reversed scored

\section{Field Test}

Prior to administering the formal pilot test, an informal field test was conducted to confirm face validity and to verify that the response items and instrument directions were clear. Five veteran D-III coaches with over 15 years of experience completed the questionnaire focusing on item comprehension and the ease of responding to each item. Based on suggestions, minor modifications were made to three items. The feedback indicated that the instrument was direct, straightforward, and succinct. Consequently, it remained intact as a 30-item scale.

\section{Small Scale Exploration}

Coaches at four NCAA D-III university athletic departments participated in an initial study to explore the construct validity and reliability measures of the ADTS. Selection of these four private, liberal arts universities was intentional, as they were representative of the entire DIII population. According to the NCAA, $81 \%$ of D-III members are private institutions, on average $24 \%$ of the student body are athletes, and the average school offers 18 sports (NCAA, 2016). Athletes at the four selected private schools, on average, accounted for $20.75 \%$ of the student body and each institution participated in an average of 14.5 sports.

Upon obtaining institutional review board (IRB) approval from all institutions in the study, the principal investigator emailed an electronic version of the ADTS to all coaches at each institution. The scale asked coaches to respond to items about their athletic director; yet because one institution's athletic director was also the head coach of a team, he did not receive an invitation to participate in the study. One hundred coaches received a solicitation email and two follow-up emails. Participants were asked to respond to the 30 -item inventory (11 trust in athletic 
director items, 10 trust in student-athlete items, and nine trust in coaching staff items) by indicating their level of agreement measured using a six-point Likert-type scale, ranging from strongly disagree (1) to strongly agree (6). Fifty-one coaches responded to the survey, for a response rate of $51 \%$.

A principal components analysis with a direct oblimin rotation was used to analyze construct validity of the 30 -item ADTS. The goal of the analysis was to reduce instrument size without substantially disrupting the factor structure or the reliability of the survey. An additional goal was to ensure that all five facets of organizational trust were included for each referent group (Shoho \& Smith, 2004). Specifically, the following criteria were applied: (a) only factors with an eigenvalue of 1.0 or greater were extracted (Hair, Anderson, Tatham, \& Black, 2004); (b) items with factors loadings of at least .400 and without cross-loadings of .500 on more than two factors were retained (Field, 2005); (c) each factor with an alpha coefficient equal to or greater than .50 on the reliability test were considered acceptable (Baumgartner \& Jackson, 1999); and (d) items that reduced the reliability of a factor were eliminated (Kerlinger, 1973). Three factors were identified with a total of $71.84 \%$ variance explained. The factors were labeled as trust in athletic director, trust in coaching staff, and trust in student-athlete. Two items which violated the criteria for retention were subsequently removed: "The student-athletes in our department talk freely about their lives outside of college" and "Student-athletes in our department cheat if they have a chance." After removing those items, a second analysis of the ADTS produced a 28 -item survey that reliably measured three dimensions of trust: trust in athletic director $($ alpha $=.974)$, trust in coaching staff $($ alpha $=.908)$, and trust in student-athletes $($ alpha $=.900)$. The three-factor structure with 28 total items was similar to the instrument used as a conceptual model for the ADTS. As a result, it was determined that the scale was appropriate to use in further exploration of organizational trust in DIII athletic departments. The next step in the design process was to evaluate the ADTS using a more comprehensive sample. To that end, data were collected from a large sample $(n=405)$ of NCAA D-III coaches. According to Field (2005), a sample of more than 300 is sufficient to provide a stable factor solution.

\section{Pilot Test}

The population consisted of coaches from a stratified random sample of 444 athletic departments competing at the DIII level. Specifically, a random sample was taken from the top quartile as well as those not earning any points in the previous year's National Association of Collegiate Directors of Athletics (NACDA) Cup rankings. The NACDA Cup ranks overall athletic department success based on post-season competition. This random selection technique allowed for a cross-section of athletic departments that experienced varying degrees of success. Additionally, this stratification facilitated the creation of a dichotomous variable, which could be useful in future analysis. Given the exploratory nature of this investigation, however, the focus was on attaining individual perceptions of coaching staff trust across the spectrum of institutions.

Using a random number table (Babbie, 1995) the researcher identified 31 schools from the top quartile and 33 from those earning zero NACDA points. Five invited schools from the bottom strata declined to participate. The final sample therefore consisted of 59 schools located in twenty states ( 31 from the top quartile and 28 from the last place group). A total of 1,326 individual coaches from the 59 schools were invited to participate, of which, 405 completed the survey for a response rate was $30.5 \%$. See Table 2 for a demographic representation of the 
sample. Previous research has indicated the response rate is in-line with the averages for on-line surveys (Dillman, Smyth, \& Christian, 2008).

Table 2 Demographic Representation of the Sample $(n=405)$

\begin{tabular}{ccc}
\hline Tenure at Current & \multicolumn{2}{c}{ Coaching Level $(n=369)$} \\
\cline { 2 - 3 } Institution $(n=369)$ & $\begin{array}{c}\text { Head } \\
\text { Coach }\end{array}$ & $\begin{array}{c}\text { Assistant } \\
\text { Coach }\end{array}$ \\
\hline $1-5$ years & 107 & 106 \\
$6+$ years & 134 & 22 \\
Tenure as a College & & \\
Coach $(n=360)$ & & 87 \\
\hline $1-5$ years & 50 & 37 \\
$6+$ years & 186 &
\end{tabular}

Notes: Some participants did not report either their tenure or coaching level.

Data were collected using an electronic version of the 28-item ADTS with the web-based survey administration program Survey Monkey. While there are issues associated with the use of surveys to uncover respondent perceptions (Babbie, 1995), the assumption was that participants were honest and forthright. The solicitation email included a link to the survey and the password required to access the ADTS. Additionally, the email contained a brief introductory letter that explained the purpose of the study and specified efforts employed to maintain respondent anonymity and confidentiality. To that end, no names or other identifying characteristics (e.g., name of the sport coached, race, ethnicity, gender of the respondents) other than length of employment, tenure as a coach, and coaching classification (head or assistant) were included in the ADTS.

\section{Analysis}

The principal objective was to refine the ADTS. To that end, a principal components analysis was employed to examine the factor structure of the 28-item ADTS to determine if the factor structure for this larger sample would reflect the findings of the previous analysis.

Additionally, the instrument was assessed for reliability using Cronbach's alpha. To ensure there were no corrupt data, descriptive statistics were calculated for each trust dimension. As a means to explore the relationship between the three factors, correlation coefficients were calculated for each element. Additionally, the results of Analysis of Variance (ANOVA) tests were examined to answer the three guiding research questions.

\section{Results}

The first step in the data analysis process was to derive the descriptive statistics for the three factors of athletic department trust: coaching staff's trust in (1) athletic director, (2) coaching staff (colleagues), and (3) student-athletes (see Table 3). An examination of ranges, means, and standard deviations uncovered no findings to prevent further analysis. 
Table 3. Descriptive Statistics of Athletic Department Trust Factors

\begin{tabular}{|c|c|c|c|c|c|}
\hline Variable & Mean & $\begin{array}{c}\text { Standard } \\
\text { Deviation }\end{array}$ & Range & Minimum & Maximum \\
\hline $\begin{array}{l}\text { Coaching Staff's Trust in } \\
\text { Coaching Staff }\end{array}$ & 4.4742 & .62765 & 3.11 & 2.78 & 5.89 \\
\hline $\begin{array}{l}\text { Coaching Staff's Trust in the } \\
\text { Athletic Director }\end{array}$ & 4.4806 & .78928 & 3.93 & 1.64 & 5.57 \\
\hline $\begin{array}{l}\text { Coaching Staff's Trust in } \\
\text { Student-Athletes }\end{array}$ & 4.5020 & .44358 & 2.05 & 3.25 & 5.30 \\
\hline
\end{tabular}

\section{Factor Structure and Reliability Analysis}

The construct of organizational trust is new in the examination of NCAA athletic departments. It was therefore necessary to conduct an analysis to check the ADTS' stability, to refine the instrument, to ensure all items loaded appropriately, and to assess construct validity. Principal components analysis was performed and compared to results from the prior analysis. Because it was suspected that emergent factors would be correlated, an oblique Oblimin rotation with Kaiser Normalization was the extraction method applied to all 28 -items. Using a scree test with eigenvalues greater than one, the analysis yielded three strong factors, indicating that the factor structure of the instrument was methodologically sound (Field, 2005). These factor loadings were consistent in comparison to the results of the previous analysis.

Factor 1 described how coaches perceived the general degree of trust for their athletic director. Trust in Athletic Director (TAD) had strong factor loadings between .776 and .886 and it explained $29.32 \%$ of the cumulative variance. Factor 2 described how the coaching staff perceived their trust in coaching staff (TCS). TCS had strong factor loadings between .459 and .854 and explained $22.44 \%$ of the cumulative variance. Factor 3 described how the coaching staff perceived their trust in student-athletes. Trust in Student-Athlete (TSA) also had strong factor loadings between .586 and .789 and it explained $15.37 \%$ of the cumulative variance. The cumulative variance explained by all three factors was $67.13 \%$. See Table 4 for the complete factor analysis of the ADTS.

Table 4 Factor Analysis of the Athletic Department Trust Scale

Item

\section{Trust in Athletic Director (TAD)}

The coaching staff in our department can rely on the A.D.

The A.D. in our department is unresponsive to the coaching staff's concerns $\quad .880$

The coaching staff in our department has faith in the integrity of the A.D.

The coaching staff in our department trust their A.D.

The A.D. in our department typically acts with the best interest of the
.886

.875

Factor

Loadings

.873

.845 
coaching staff in mind

The A.D. in our department is competent in performing his or her job

.845

The A.D. openly shares information with the coaching staff

.828

The coaching staff in our department is suspicious of most of the A.D.'s actions

The A.D. in our department keeps his or her word

The A.D. in our department does not show concern for the coaching staff

The A.D. doesn't tell the coaching staff what is really going on $\quad .776$

Alpha Coefficient $\quad .966$

Eigenvalues 8.209

Cumulative $\%$ of the Variance

29.32

\section{Trust in Coaching Staff (TCS)}

The coaching staff in our department believes in each other

The coaching staff in our department typically looks out for each other

Even in difficult situations, the coaching staff in our department can depend upon each other

.826

The coaching staff in our department trusts each other

The coaching staff in our department is open with each other

When the coaching staff in our department tells you something you can believe what they say

The coaching staff in our department is suspicious of each other

The coaching staff in our department has faith in the integrity of their colleagues

The coaching staff in our department is not competent in their coaching abilities

Trust in Student-Athlete (TSA)

Student-athletes in our department can be counted on to do their work

Student-athletes in our department are reliable

The coaching staff in our department trusts their student-athletes

The coaching staff in our department believes what student-athletes say

The student-athletes in our department have to be closely supervised 
The coaching staff in our department believes student-athletes are competent in their ability to learn new skills

.632

.586

Student-athletes in our department are caring towards one another

Alpha Coefficient

.864

Eigenvalues

4.303

Cumulative $\%$ of the Variance

Next, reliability coefficients were calculated for the three dimensions of athletic department trust. The results for each subset were strong. The resultant Cronbach alpha levels for each factor were: TAD .966, TCS .944, and TSA .864. Additionally, intercorrelations were calculated among the factors of the ADTS. Not surprisingly, moderate to strong positive correlations existed among the three dimensions of athletic department trust. However, it should be noted that TAD did not have a significant relationship with TSA $(r=.246, n$.s.). See Table 5 for correlations and alpha coefficients. The exploration yielded an instrument composed of three subsets: an 11-item measure of trust in athletic director, a nine-item measure of trust in coaching staff, and an eight-item measure of trust in student-athletes. Next, the researcher explored relationships between the three factors of trust and personal characteristics of the respondents.

Table 5 ADTS Intercorrelations and Alpha Coefficients of Reliability

\begin{tabular}{lccc}
\hline & $\begin{array}{c}\text { Coaches' Trust in } \\
\text { Coaching Staff }\end{array}$ & $\begin{array}{c}\text { Coaches' Trust in } \\
\text { Athletic Director }\end{array}$ & $\begin{array}{c}\text { Coaches' Trust } \\
\text { in Student- } \\
\text { Athlete }\end{array}$ \\
\hline $\begin{array}{l}\text { Coaching Staff's Trust in } \\
\text { Coaching Staff }\end{array}$ & $(.944)$ & $.598^{* *}$ & $.432^{* *}$ \\
$\begin{array}{l}\text { Coaching Staff's Trust in } \\
\text { Athletic Director } \\
\text { Coaches' Trust in Student- } \\
\text { Athletes }\end{array}$ & $(.966)$ & .246 \\
\hline
\end{tabular}

**. Correlation is significant at the 0.01 level (2-tailed).

Alpha coefficients of reliability for the factors are displayed in parentheses.

\section{Trust, Tenure, and Coaching Classification}

Specific personal characteristics explored in this study were tenure as a college coach, tenure at the current institution, and coaching classification (head coach or assistant coach). These features were examined based on the relative importance afforded to each in intercollegiate athletic departments.

To address the first research question, mean scores on the three subscales were compared. The ANOVA revealed that coaches with six or more years of experience $(M=4.38, S D=1.24)$ had lower levels of trust in their athletic director than did coaches with one to five years of experience $(M=4.66, S D=0.99)$. This difference was significant, $F(1,309)=4.68, p<.05$; however, the effect size was small, $\omega=.10$. There were no significant differences between the two groups of coaches on the two other measures of organizational trust (see Table 6). 
Table 6 Mean and Standard Deviations for Years as a College Coach on Trust Subscales

\begin{tabular}{|c|c|c|c|c|c|c|}
\hline & \multicolumn{2}{|c|}{$\begin{array}{c}\text { Coaches' Trust in } \\
\text { Coaching Staff }\end{array}$} & \multicolumn{2}{|c|}{$\begin{array}{l}\text { Coaches' Trust in } \\
\text { Athletic Director }\end{array}$} & \multicolumn{2}{|c|}{$\begin{array}{l}\text { Coaches' Trust in } \\
\text { Student-Athlete }\end{array}$} \\
\hline & $M$ & $S D$ & $M$ & $S D$ & $M$ & $S D$ \\
\hline $1-5$ years & 4.55 & 0.91 & 4.66 & 0.99 & 4.59 & 0.64 \\
\hline $6+$ years & 4.44 & 0.94 & 4.38 & 1.24 & 4.58 & 0.67 \\
\hline F-score & \multicolumn{2}{|c|}{0.954} & \multicolumn{2}{|c|}{4.211} & \multicolumn{2}{|c|}{.008} \\
\hline p-value & \multicolumn{2}{|c|}{.329} & \multicolumn{2}{|c|}{.041} & \multicolumn{2}{|c|}{.930} \\
\hline
\end{tabular}

An ANOVA was conducted to answer the second research question. Results revealed that coaches employed at their current institution between one and five years $(M=4.58, S D=1.08)$ had higher levels of trust in their athletic director than did coaches employed six or more years $(M=4.31, S D=1.25)$. This difference was significant, $F(1,317)=3.93 p<.05, \omega=.10$. There were no significant differences on the two other measures of organizational trust (see Table 7).

Table 7 Mean and Standard Deviations for Years Coaching at Institution on Trust Subscales

\begin{tabular}{|c|c|c|c|c|c|c|}
\hline & \multicolumn{2}{|c|}{$\begin{array}{c}\text { Coaches' Trust in } \\
\text { Coaching Staff }\end{array}$} & \multicolumn{2}{|c|}{$\begin{array}{l}\text { Coaches' Trust in } \\
\text { Athletic Director }\end{array}$} & \multicolumn{2}{|c|}{$\begin{array}{l}\text { Coaches' Trust in } \\
\text { Student-Athlete }\end{array}$} \\
\hline & $M$ & $S D$ & $M$ & $S D$ & $M$ & $S D$ \\
\hline $1-5$ years & 4.48 & 0.92 & 4.58 & 1.08 & 4.53 & 0.68 \\
\hline $6+$ years & 4.47 & 0.95 & 4.31 & 1.25 & 4.63 & 0.62 \\
\hline F-score & \multicolumn{2}{|c|}{0.15} & \multicolumn{2}{|c|}{4.132} & \multicolumn{2}{|c|}{1.704} \\
\hline $\mathrm{p}$-value & \multicolumn{2}{|c|}{.904} & \multicolumn{2}{|c|}{.043} & \multicolumn{2}{|c|}{.193} \\
\hline
\end{tabular}

The ANOVA to answer research question three revealed no significant differences between head coaches and assistant coaches on the three measures of organizational trust (see Table 8). 
Table 8 Mean and Standard Deviations for Coaching Classification on Trust Subscales

\begin{tabular}{|c|c|c|c|c|c|c|}
\hline & \multicolumn{2}{|c|}{$\begin{array}{c}\text { Coaches' Trust in } \\
\text { Coaching Staff }\end{array}$} & \multicolumn{2}{|c|}{$\begin{array}{l}\text { Coaches' Trust in } \\
\text { Athletic Director }\end{array}$} & \multicolumn{2}{|c|}{$\begin{array}{l}\text { Coaches' Trust in } \\
\text { Student-Athlete }\end{array}$} \\
\hline & $M$ & $S D$ & $M$ & $S D$ & $M$ & $S D$ \\
\hline Head Coach & 4.52 & 0.89 & 4.41 & 1.23 & 4.58 & 0.65 \\
\hline Assistant Coach & 4.37 & 0.99 & 4.57 & 1.00 & 4.57 & 0.67 \\
\hline F-score & \multicolumn{2}{|c|}{1.787} & \multicolumn{2}{|c|}{1.189} & \multicolumn{2}{|c|}{.021} \\
\hline p-value & \multicolumn{2}{|c|}{.182} & \multicolumn{2}{|c|}{.267} & \multicolumn{2}{|c|}{.884} \\
\hline
\end{tabular}

\section{Discussion}

The purpose of this study was to refine an instrument to measure organizational trust in intercollegiate athletic departments and to test the utility of the instrument by examining the relationship of trust among coaches using various employment variables. The results of the study support the use of organizational trust, as previously developed among educational leadership scholars, in an intercollegiate athletic department setting. A major finding in this study was confirming that the instrument has a three factor structure. The ADTS showed strong internal consistency in measuring three trust constructs: a) trust in athletic director, 2) trust in coaching staff, and 3) trust in student-athletes. Additionally, the ADTS measures all trust facets, including vulnerability, in each referent group, which affirms operationalizing trust to include benevolence, competency, honesty, openness, and reliability.

An examination of the mean scores revealed the lowest score to be a 4.31 (on a 6.0 scale), which indicates that NCAA D-III athletic departments appear to be trusting workplaces. Deeper analysis into the data, however, reveals important questions. Though it might be a surprise to uncover the inverse relationship between coaching tenure and trust in athletic director, it supports Smith and Shoho (2007) who found an inverse relationship between faculty tenure and trust in dean. While not statistically significant, mean scores also revealed that head coaches also tended to trust their athletic directors at lower levels than assistant coaches. What does this indicate? Possibly, less experienced coaches and those with less tenure tend to extend greater levels of trust to the athletic director based on a concept described as role-based trust (Kramer, 1999). This phenomenon occurs when an individual is trusted based upon her role in the organization, based on the lack of personalized evidence (Kramer, 2010) as opposed to trust that is earned through a revelation of motivations and competencies. Perhaps concerns about job security, increased family pressures, and a culture that nurtures autonomy and self-sufficiency lead to an erosion of trust in supervisor. The findings are especially troublesome given the importance of trust in supervisor found in previous research. For example, Dirks (2000) and Schaubroeck et al. 
(2011) found that when organizational members trust their superiors, they are more likely to engage in organizational citizenship behaviors and other actions that positively impact team performance (cf. Kouzes \& Posner, 2012; Tyler \& Kramer, 1990). Tan and Tan (2000) found that both satisfaction and increased innovation were positively and significantly correlated with trust in supervisor.

Previous research indicates that trust takes time to develop (Baier, 1986; Goddard et al., 2001; Jones \& George, 1998; McEvily et al., 2003). These findings, however hint that the opposite might hold true in jobs with high levels of autonomy. Additionally, the apparent trust erosion that accompanies longevity in the coaching profession has serious ramifications for those concerned with developing a healthier and more transparent intercollegiate sports environment. These findings spark the question: What organizational processes sustain or undermine the maintenance of athletic department trust? This question provides a strong foundation for further exploration. Sustained research into organizational trust could assist in discovering reasons why athletic department cultures are leery of outsiders and slow to change (Coakley, 2008). The author promotes its additional use for further validation of it as a useful tool to explore athletic department trust (contact the author to obtain a complete version of the ATDS). As an exploratory study, however, this research contained some limitations.

\section{Limitations}

Though great care was taken with sampling techniques and data analysis procedures, this study is not void of limitations. First, the survey methodology used for this study relied on perceptions of the respondents. As with all self-reported data, some caution should be used when generalizing. There is no reason to believe that respondents were not forthright, but the perceptions expressed in their responses may indeed not accurately reflect the nature of their workplace. Second, the response rate reflects the difficulties in collecting data from this population. This issue points to the inherent difficulties associated with studying organizational functions in college athletic departments (Coakley, 2008). The research questions, while appropriate for an exploratory study, did not lead to deeper levels of analysis, (e.g., regression, SEM, MANCOVA) which might reveal other important information. The exclusive use of NCAA D-III institutions as the study population is another limitation. The limitations of this study, however, point to opportunities for future research.

\section{Research Implications}

The intention of this study was to develop an instrument useful for measuring the level of organizational trust in an intercollegiate athletic department. To that end, this research adds to the existing organizational trust literature and it begins to extend this connection into the sport management field. Exploring the construct of organizational trust in athletic departments could be an important element in a multi-pronged approach to examining the various extant cultures in American higher education. To be sure, the examination of organizational trust in intercollegiate athletic departments provides rich soil for future research. As such, possible future studies might include:

1. A more detailed exploration of the impact of coaching staff tenure on the development of organizational trust. Does the length of time a coach has worked for the current athletic director matter?

2. Will the results be similar with athletic departments that offer athletic grants-in-aid? 
3. What is the nature of the relationship between coaches' trust in athletes and on-the-field success, such as winning games?

4. What is the impact of the athletic director's leadership style on organizational trust? Is there a leadership approach more likely to develop this organizational process?

Continued trust research may well assist in unearthing reasons for how certain organizational processes operating in intercollegiate departments of athletics might obfuscate reform efforts.

\section{Practical Implications}

Although this research is exploratory, it highlights important issues. First, the ADTS is a parsimonious, valid, and reliable research instrument, which assesses the degree of organizational trust in athletic departments and measures the extent to which coaches trust their colleagues, their athletic director, and their athletes. Second, it appears as if longevity in the coaching profession leads to diminished levels of trust in athletic director. As such, it appears to be a useful instrument for university administrators and athletic directors interested in evaluating the levels of trust in their athletic department. The scale presents, for either a university administrator or an athletic director, an anonymous and confidential approach to gathering information about an important organizational process, which may have a relationship with positive workplace outcomes.

Athletic directors seeking to explore the level of trust in their department can benefit from employing the instrument refined in this study. The ADTS is a valuable tool to determine coaches' perceptions about the benevolence, competence, honesty, openness, and reliability of their athletic director, fellow coaches, and their athletes. Specifically, information derived from this instrument can provide athletic directors a deeper understanding of the cultural environment of their departments. Furthermore, an athletic director who is aware of the relationship between trust and positive work outcomes in other environments may choose to hire coaches with demonstrated trustworthy behaviors. Additionally, university administrators who are cognizant of those connections may choose to hire a director of athletics more likely to create an organizational climate in which trusting behaviors are recognized and rewarded.

Moreover, university administrators can use the ADTS to undercover the coaching staff's perceptions regarding the trustworthiness of the athletic director. In essence, by using this measure, administrators may get a glimpse of a key organizational process through the eyes of athletic department personnel - a look not often afforded. A sketch of current levels of organizational trust might then be drawn, and determinations be made, as to whether the organizational culture is in need of attention.

As with an individual, the more self-aware an organization is, the more effective it can be. Using the ADTS to develop an understanding of trust issues might pave the way for the application of interventions to improve team dynamics.

\section{Conclusion}

Based on an extensive literature review, a multi-faceted definition of trust was developed. As such, athletic department trust is “one party's willingness to be vulnerable to another party because of the confidence that the latter party is benevolent, reliable, competent, honest, and open" (Hoy \& Tchannen-Moran, 1999, p. 189). This operationalization of trust was supported through construct analysis. All facets of trust were demonstrated for each dimension of trust: trust in athletic director, trust in coaching staff, and trust in student-athlete. Furthermore, the 
subscales generated reliable and valid measures, which positively correlated. Trust continues to be an important variable in the operations of higher education institutions and is perhaps even more significant in the high profile area of intercollegiate athletics. As such, the development of the ATDS can be considered an important development for both scholars and practitioners.

\section{References}

Babbie, E. R. (1995). The practice of social research (7th ed.). Belmont, CA: Wadsworth.

Baier, A. (1986). Trust and antitrust. Ethics, 96, 231-260.

Barney, J. B., \& Hansen, M. H. (1994). Trustworthiness as a source of competitive advantage. Strategic Management Journal, 15, 175-190. dOI: 10.1002/smj.4250150912

Baumgartner, T. A., \& Jackson, A. S. (1999). Measurement for evaluation in physical education and exercise science (6th ed.). Boston, MA: W. C. Brown.

Brenkert, G. G. (1997). Marketing trust: Barriers and bridges. Business \& Professional Ethics Journal, 16, 77-98.

Bromiley, P., \& Cummings, L. L. (1995). Transactions costs in organizations with trust. In R. J. Bies, B. Sheppard, \& R. J. Lewicki (Eds.), Research in negotiations in organizations (Vol. 5, pp. 219247). Greenwich, CT: JAI Press.

Butler, J. K., \& Cantrell, R. S. (1984). A behavioral decision theory approach to modeling dyadic trust in superiors and subordinates. Psychological Reports, 55, 19-28.

Chelladurai, P., \& Ogasawara, E. (2003). Satisfaction and commitment of American and Japanese collegiate coaches. Journal of Sport Management, 17, 62-73.

Clotfelter, C. T. (2011). Big-time sports in American universities. New York, NY: Cambridge University Press.

Coakley, J. (2008). Studying intercollegiate sports: High stakes, low rewards. Journal of Intercollegiate Sport, 1, 14-28.

Cunningham, J. B., \& MacGregor, J. (2000). Trust and the design of work: Complementary constructs in satisfaction and performance. Human Relations, 53, 1575-1591. dOI: $10.1177 / 00187267005312003$

Dietz, G., \& Den Hartog, D. N. (2006). Measuring trust inside organizations. Personnel Review, 35, 557-588. dOI: 10.1108/00483480610682299

Dillman, D. A., Smyth, J. D., \& Christian, L. M. (2008). Internet, mail, and mixed-mode surveys: The tailored design method. New York, NY: John Wiley and Sons.

Dirks, K. T. (1999). The effects of interpersonal trust on work group performance. Journal of Applied Psychology, 84, 445-455. dOI: /10.1037/0021-9010.84.3.445

Dirks, K. T. (2000). Trust in leadership and team performance: Evidence from NCAA basketball. Journal of Applied Psychology, 85, 1004-1012. dOI: http://dx.doi.org/10.1037/00219010.85.6.1004

Dirks, K. T., \& Ferrin, D. L. (2001). The role of trust in organizational settings. Organization Science, 12, 450-467. dOI: $10.1287 /$ orsc.12.4.450.10640

Dirks, K. T., \& Ferrin, D. L. (2002). Trust in leadership: Meta-analytic findings and implications for organizational research. Journal of Applied Psychology, 87, 611-628. dOI: 10.1037/00219010.87.4.611

Dirks, K. T., \& Skarlicki, D. P. (2004). Trust in leaders: Existing research and emerging issues. In R. M. Kramer \& K. S. Cook (Eds.), Trust and distrust in organizations: Dilemmas and approaches (Vol. 7, pp. 21-40). New York, NY: The Russell Sage Foundation. 
Field, A. (2005). Discovering statistics using SPSS (2nd ed.). London: Sage.

Gabarro, J. J. (1978). The development of trust influence and expectations. In A. G. Athos \& J. J. Gabarro (Eds.), Interpersonal behavior communication and understanding in relationships (pp. 290-303). Englewood Cliffs, NJ: Prentice-Hall.

Gambetta, D. (1988). Can we trust? In D. Gambetta (Ed.), Trust: Making and breaking cooperative relations (pp. 213-237). New York, NY: Basil Blackwell.

Gerdy, J. R. (2006). Air ball: American education's failed experiment with elite athletics. Jackson, MS: University Press of Mississippi.

Goddard, R. D., Tschannen-Moran, M., \& Hoy, W. K. (2001). A multilevel examination of the distribution and effects of teacher trust in students and parents in urban elementary schools. The Elementary School Journal, 102, 3-17. http://www.jstor.org/stable/1002166

Gould, D., Guinan, D., Greenleaf, C., \& Chung, Y. (2002). A survey of U.S. Olympic coaches: Variables perceived to have influenced athlete performances and coach effectiveness. The Sport Psychologist, 16, 229-250.

Hair, F. H., Anderson, R. E., Tatham, R. L., \& Black, W. C. (2004). Multivariate data analysis (5th ed.). Upper Saddle River, NJ: Prentice Hall.

Hosmer, L. T. (1995). Trust: The connecting link between organizational theory and philosophical ethics. Academy of Management Review, 20, 379-403. dOI:10.5465/AMR.1995.9507312923

Hoy, W. K. (2002). Faculty trust: A key to student achievement. Journal of School Public Relations, 23, 88-103.

Hoy, W. K., Gage, C. Q., \& Tarter, C. J. (2006). School mindfulness and faculty trust: Necessary conditions for each other? Educational Administration Quarterly, 42, 236-255.

dOI: 10.1177/0013161X04273844

Hoy, W. K., \& Tschannen-Moran, M. (1999). Five faces of trust: An empirical confirmation in urban elementary schools. Journal of School Leadership, 9, 184-208.

Hoy, W. K., \& Tschannen-Moran, M. (2003). The conceptualization and measurement of faculty trust in schools. In W. K. Hoy \& C. G. Miskel (Eds.), Studies in leading and organizing schools (pp. 181-207). Greenwich, CT: Information Age Publishing.

Huang, H. J., \& Dastmalchian, A. (2006). Implications of trust and distrust for organizations: Role of customer orientation in a four-nation study. Personnel Review, 35, 361-377. dOI: 10.1108/ 00483480610670553

Jones, G. R., \& George, J. M. (1998). The experience and evolution of trust: Implications for cooperation and teamwork. Academy of Management Review, 23, 531-546. dOI: 10.5465/AMR.1998.926625

Kerlinger, F. N. (1973). Foundations of behavioral research (2nd ed.). New York, NY: Holt, Rinehart, and Winston.

Kerwin, S., \& Doherty, A. (2012). An investigation of the conflict triggering process in intercollegiate athletic departments. Journal of Sport Management, 26, 224-236.

Kihl, L. A., \& Richardson, T. (2009). "Fixing the mess": A grounded theory of a men's basketball coaching staff's suffering as a result of academic corruption. Journal of Sport Management, 23, 278-304.

Kouzes, J. M., \& Posner, B. Z. (2012). The leadership challenge (5th ed.). San Francisco, CA: JosseyBass.

Kramer, R. M. (1999). Trust and distrust in organizations: Emerging perspectives, enduring questions. Annual Reviews: Psychology, 50, 569-598. dOI: 10.1146/annurev.psych.50.1.569 
Kramer, R. M. (2010). Collective trust within organizations: Conceptual foundations and empirical insights. Corporate Reputation Review, 13, 82-97. dOI:10.1057/crr.2010.9

Lorenz, E. H. (1988). Neither friends nor strangers: Informal networks of subcontracting in French Industry. In D. Gambetta (Ed.), Trust: Making and breaking cooperative relations (pp. 194-210). New York, NY: Basil Blackwell.

Malloy, D. C., \& Zakus, D. H. (1995). Ethical decision making in sport administration: A theoretical inquiry into substance and form. Journal of Sport Management, 9, 36-58.

Mathieu, J. E., \& Zajac, D. M. (1990). A review and meta-analysis of the antecedents, correlates, and consequences of organizational commitment. Psychological Bulletin, 108, 171-194. dOI: 10.1037/0033-2909.108.2.171

Mayer, R. C., Davis, J. H., \& Schoorman, F. D. (1995). An integrative model of organizational trust. Academy of Management Review, 20, 709-734. http://www.jstor.org/stable/258792

McAllister, D. J. (1995). Affect- and cognition-based trust as foundations for interpersonal cooperation in organizations. Academy of Management Journal, 38, 24-59. http://www.jstor.org/stable/256727

McEvily, B., Perrone, V., \& Zaheer, A. (2003). Trust as an organizing principle. Organization Science, 14,91-103. dOI: 10.1287/orsc.14.1.91.12814

McQueary, K. J. (1997). Relationship between head coach turnover and team performance in NCAA Division I-A football programs from 1978-1995. Unpublished Dissertation, University of Texas, Austin, TX.

Mishra, A. K. (1996). Organizational responses to crisis: The centrality of trust. In R. M. Kramer \& T. R. Tyler (Eds.), Trust in organizations: Frontiers of theory and research (pp. 261-287). Thousand Oaks, CA: Sage Publications.

Mitten, M. J., Musselman, J. L., \& Burton, B. W. (2009). Commercialized intercollegiate athletics: A proposal for targeted reform consistent with American cultural forces and marketplace realities. Journal of Intercollegiate Sport, 2, 202-232.

National Collegiate Athletic Association (NCAA). (2016). NCAA Division III facts and figures. Indianapolis, IN: NCAA. Retrieved, June 9, 2016 from https://www.ncaa.org/sites/default/files/201516\%20DIII\%20Facts\%20and\%20Figures\%20with\%20Budget\%20Facts.pdf.

Nooteboom, B. (2007). Social capital, institutions, and trust. Review of Social Economy, 65, 29-53. dOI: $10.1080 / 00346760601132154$

Pfeffer, J. (1993). Barriers to the advancement of organizational science: Paradigm development as a dependent variable. Academy of Management Review, 18, 599-620. http://www.jstor.org/stable/258592

Pope, M. L. (2004). A conceptual framework of faculty trust and participation in governance. New Directions for Higher Education, 127, 75-84. dOI: 10.1002/he.157

Rousseau, D., Sitkin, S. B., Burt, R., \& Camerer, C. (1998). Not so different after all: A cross-discipline view of trust. Academy of Management Review, 23, 393-404. http://www.jstor.org/stable/259285

Schaubroeck, J., Lam, S. K., \& Peng, A. (2011). Cognition-based and affect-based trust as mediators of leader behavior influences on team performance. Journal of Applied Psychology, 96, 863-871. dOI: $10.1037 / \mathrm{a} 0022625$

Shoho, A. R., \& Smith, P. A. (2004). An exploratory analysis of faculty trust in higher education. In W. K. Hoy \& C. G. Miskel (Eds.), Educational administration, policy, and reform: Research and measurement (pp. 279-303). Greenwich, CT: Information Age Publishing. 
Smerek, R. E., \& Peterson, M. (2006). Examining Herzberg's theory: Improving job satisfaction among non-academic employees at a university. Research in Higher Education, 48, 229-250. dOI: $10.1007 / \mathrm{s} 11162-006-9042-3$

Smith, P. A., \& Shoho, A. R. (2007). Higher education trust, rank, and race: A conceptual and empirical analysis. Innovative Higher Education, 32, 125-138. dOI: 10.1007/s 10755-007-9042-z

Snyder, C. J. (1990). The effects of leader behavior and organizational climate on intercollegiate coaches' job satisfaction. Journal of Sport Management, 4, 59-70.

Tan, H. H., \& Tan, C. F. (2000). Toward the differentiation of trust in supervisor and trust in organization. Genetic, Social, \& General Psychology Monographs, 126, 241-260.

Thelin, J. (1996). Games colleges play: Scandal and reform in intercollegiate athletics. Baltimore, MD: The Johns Hopkins University Press.

Tschannen-Moran, M. (2004). Trust matters: Leadership for successful schools. San Francisco, CA: Jossey-Bass.

Turner, B. A. (2001). Commitment among intercollegiate athletic coaches. (Unpublished doctoral dissertation), The Ohio State University, Columbus, $\mathrm{OH}$.

Turner, B. A., \& Chelladurai, P. (2005). Organizational and occupational commitment, intention to leave, and perceived performance of intercollegiate coaches. Journal of Sport Management, 19, 193-211.

Tyler, T. R., \& Kramer, R. M. (1990). Why people obey the law. New Haven, CT: Yale University Press.

Weaver, M. A., \& Chelladurai, P. (2002). Mentoring in intercollegiate athletic administration. Journal of Sport Management, 16, 96-116.

Whitener, E. M., Brodt, S. E., Korsgaard, M. A., \& Werner, J. M. (1998). Managers as initiators of trust: An exchange relationship framework for understanding managerial trustworthy behavior. Academy of Management Review, 23, 513-530. http://www.jstor.org/stable/259292

Yukelson, D. (1997). Principles of effective team building interventions in sport: A direct services approach at Penn State University. Journal of Applied Sport Psychology, 9, 73-96. dOI: $10.1080 / 10413209708415385$

Yusof, A. (1998). The relationship between transformational leadership behaviors of athletic directors and coaches' job satisfaction. The Physical Educator, 55, 170-175.dOI: 10.1260/17479541.7.4.661 